\title{
Kasvibiotekniikka täyttää tänä vuonna 30 vuotta, mutta ei juhli
}

Kristiina Himanen, Milla Pietiäinen

Maataloustieteiden laitos, Latokartanonkaari 7, 000014 Helsingin yliopisto

\section{Tiivistelmä}

Moderni kasvinjalostus hyödyntää maaperän Agrobakteerin kykyä siirtää omaa DNA:ta kasvisoluun, siis yli eliökuntarajojen. Kasvin kromosomistoon siirtyvä DNA sulautuu osaksi kasvin perimää ja alistuu sen molekyylisäätelylle. Tähän luonnon molekyylien vuorovaikutukseen perustuvalla LUMO-jalostuksella on potentiaalia mullistaa kasvintuotanto ja edistää sen sopeuttamista muuttuviin ympäristöolosuhteisiin. Esimerkkejä modernista kasvinjalostuksesta ovat olleet kasveihin siirretyt yksittäisiä proteiineja tuottavat geenit, jotka antavat kasveille tietyn uuden ominaisuuden. Uusia geenitekniikoita kehitetään jatkuvasti ruokkimaan EUn tietoyhteiskunnan strategioita ja sitä kautta taloudellista kehitystä.

kasvinjalostus, geeni, Agrobakteeri, luonnon molekyylit 


\section{LUMO-jalostuksen perusteet}

Moderni kasvinjalostus perustuu kasvibiotekniikan ja geenitekniikan menetelmiin. Nimestään huolimatta biotekniikka ei ole ihmisen kehittämää teknologiaa vaan perustuu luonnon omien molekyylien vuorovaikutukseen. Evoluution myötä maaperän Agrobacterium bakteerikannalle on kehittynyt molekyylikoneisto, joka on erikoistunut siirtämään DNA:ta kasvisoluun, yli eliökuntarajojen. Kasvin tumassa, bakteerin DNA:n siirtoon erikoistuneet molekyylit etsivät sopivan kohdan kasvin kromosomistosta ja kasvin omat molekyylit sulkevat uuden DNA:n osaksi perimäänsä (Brunaud et al., 2002). Kasvin molekyylikoneisto alkaa säädellä uutta DNA:ta kuin omaansa. Jos uusi DNA on kasville epäedullinen, se vaimennetaan tai poistetaan, myöskään geenin tuote ei voi olla kasville vahingollinen. Tutkijoiden osuus geeninsiirtoteknologian kehittämisessä on ollut havaita ja ottaa käyttöön tämä bakteerin ja kasvin luonnollisten molekyylien harmonisessa vuorovaikutuksessa tapahtuva prosessi (Van Montagu, 2011).

DNA on orgaaninen biomolekyyli, joka rakentuu kahdesta sokeri-fosfaattirungosta, joita yhdistävät neljä vuorottelevaa emäsparia (A-T, C-G). DNAsta muodostuvat geenit ovat "Elämän ABC", tai oikeammin siis ACGT, ja kaiken elollisen perusedellytys. Viruksesta ihmiseen elolliset olennot ja niiden elämän säätely perustuu noiden neljän emäksen vaihtelevaan järjestykseen ja niistä muodostuvien geenien ilmenemiseen. Evoluution perintönä jaamme kaikki tätä yhteistä geeniperimää ja eroamme vain sen määrän, järjestyksen ja ilmenemisen aktiivisuuden perusteella. Ihmisellä ja apinallahan on lähes sama perimä, sillä $96 \%$ geeneistä on yhteisiä. Vain tuon perimän ilmenemisen aktiivisuus selittää ilmiasujen erot. Erot sinun ja minun välillä johtuvat mutaatioista. Elämän monimuotoisuus perustuu geenien muunteluun, tuon Elämän ACGTn järjestyksessä nähtävään vaihteluun. Biologiassa muuntelu on jatkuvaa ja myös ehdoton edellytys evoluutiolle ja kehitykselle. Geenien ilmenemisen muutosten takia luonto näyttää joka päivä erilaiselta. Jos geenimuuntelulla tuotettu organismi (GMO) olisi luonnoton, se edellyttäisi, että elämän ACGTn toimintaperiaatteisiin puututtaisiin jollain luonnottomalla tavalla. Näinhän ei kuitenkaan tehdä, vaan geeniteknologiassa hyödynnetään luonnon omia molekyylejä. Ehdotammekin GMO jalostuksen uudeksi nimeksi LUMO jalostusta (sanoista luonnon molekyylit).

Vuonna 1983 Agrobakteerin biologiaan perustuvat kasvibiotekniikan perusmenetelmät oli kehitetty samanaikaisesti Euroopan ja Yhdysvaltojen yliopistoissa (Angenon et al., 2013). Tutkijoille oli välittömästi selvää miten tämä löytö tulisi mullistamaan kasvinjalostuksen. Luonnon omilla DNA molekyyleillä voitaisiin välittää kasveille yksittäisiä uusia ominaisuuksia, joita kasvi tuottaisi luonnonmukaisesti osana omaa biologiaansa. Siitä lähtien Yhdysvalloissa, jossa sekä keksinnöt että maatalous ovat arvossaan, on kehitetty useita maataloustuotantoa edistäviä lajikkeita. Esimerkkinä vaikka Bt-maissi, joka tuottaa Bacillus thuringiensis bakteerista saadun geenin avulla proteiinia, joka luonnossakin toimii tiettyjä tuhohyönteisiä vastaan. Näitä lajikkeita kasvattamalla on pystytty vähentämään hyönteismyrkkyjen käyttöä merkittävästi ja viime vuosina Intiassa Bt puuvilla on nostanut tuotantomääriä suorastaan räjähdysmäisesti (www.isaaa.org). Samoja Bt kideproteiineja ruiskutetaan myös luomuviljelmille. Näin pitkän ja menestyksekkään kasvibiotekniikan historian perusteella ei siis enää ole syytä olettaa, että tällaisia DNA molekyyliä sisältävät viljelykasvit olisivat haitallisia ravinnoksi tai rehuksi käytettynä. Kultainen riisi on hyvä esimerkki tulevaisuuden geenitekniikan mahdollisuuksista. Maailman laajuisesti A-vitamiinin puutos aiheuttaa 1.5 miljoonan lapsen kuoleman vuosittain. Lisäksi A vitamiinin puutos aiheuttaa lukemattoman määrän sokeutumisia. Kultainen riisi (www.goldenrice.org) on muokattu tuottamaan A-vitamiinin esiastetta beta-karoteenia. Ruokana yleisesti käytettyyn riisilajikkeeseen on siirretty kaksi beta-karoteenin biosynteesireitin geeniä, esimerkiksi Erwinia maabakteerista (E. uredovora) sekä narsissista ( $N$. pseudonarcissus). Nämä geenit tuottavat samoja entsyymejä, jotka porkkanassakin vastaavat beta-karoteenin tuotosta. Riisikin tuottaa beta-karoteenia lehdissään, vaan ei siemenissä. 


\section{Kasvibiotekniikkaa ja maatalouspolitiikkaa}

Euroopan talouden rakenteet ovat murroksessa kun perusteollisuus jättää sen taakseen korkeiden tuotantokustannusten vuoksi. Jo vuodesta 2000 Eurooppa on etsinyt vahvuuksiaan tietotaitoyhteiskuntana ns. Lissabonin strategian mukaisesti ja nimenomaan biotekniikasta on toivottu kehittyvän korkean teknologian teollisuutta kattamaan merkittävä osuus uuden Euroopan profiilissa ja tuotannossa. Niin kutsutun Knowledge Based Bio Economy (KBBE) strategian mukaan myös siirtogeenisten viljelykasvien potentiaali pitäisi ottaa tässä kehityksessä huomioon. Käytännössä EU:n poliittinen päätöksenteko on kuitenkin luonut olosuhteet, joissa sen omien strategioiden tavoitteet eivät voi toteutua.

EU-lainsäädäntö (direktiivi 2008/27/EC ja asetus (EY) N:o 1829/2003) koskien siirtogeenisten viljelykasvien viljelyä tai myyntiä on maailman tiukin (Masip et al. 2013). Uuden siirtogeenisen lajikkeen lupakäsittely voi maksaa yli 10 miljoona ja viedä jopa viisitoista vuotta. Geenimuunneltujen (GM) kasvien turvallisuus punnitaan Euroopan elintarvikevirastossa (EFSA) yli viidenkymmenen tutkijan voimin. Myynti- tai viljelylupaa haettavan tuotteen on oltava turvallinen eikä se saa poiketa "perinteisestä" tuotteesta minkään muun ominaisuuden, kuin siirtogeenin suhteen. Lisäksi viljelylupaa haettaessa on osoitettava, ettei siirtogeeni leviä luontoon risteymien kautta tai että ns. horisontaalisesta geenin siirtymistä muihin eliölajeihin ei tapahdu. Kun siirtogeeninen kasvi on läpäissyt tämän mittavan ja varsin hintavan tieteellisen riskinarviointimenettelyn, kunkin EU-maan asiantuntijoista koostuva elin (Suomessa geenitekniikan lautakunta) antaa oman arvionsa tuotteesta. Yhteensä yli kahden sadan asiantuntijan arvio tuotteen turvallisuudesta ei vielä riitä myynti- tai viljelyluvan saamiseksi, vaan tämän lisäksi tuotteen on vakuutettava poliittiset päättäjät. Europoliitikot kävelevät kuitenkin päätöksissään jatkuvasti näiden tieteellisten arviointien ja suositusten yli. Käytännössä tämä on aiheuttanut sen, että kasvien geenitekninen jalostus on halvaantunut Euroopassa lähes täysin. Tästä Euroopalle aiheutuva taloudellinen haitta on ilmeinen ja merkittävä.

Virallisesti EU kannattaa perinteisten ja GM- lajikkeiden rinnakkaiseloa ja sallii jäsenvaltioidensa päättää minimietäisyyksistä perinteisten ja GM-lajikkeiden viljelyalueiden välillä. Rinnakkaiseloperiaate antaa mielikuvan siitä, että viljelijällä, ja lopulta myös kuluttajalla, olisi todellinen mahdollisuus valita perinteisen, luomun ja GM-viljelyn välillä. Useissa kansallisissa rinnakkaiselostrategioissa on päädytty liioiteltuihin, useiden kilometrien pituisiin suojavyöhykkeisiin. Tämä on epäsuorasti estänyt GMlajikkeiden viljelyn. Viimeaikaisessa tutkimuksessa ilmeni, että jos etäisyyssäännöksillä pyrittäisiin tukemaan todellista rinnakkaiseloa kohtuullisten minimietäisyyksien myötä, tämä muuttaisi viljelijöiden suhtautumista myönteisemmäksi GM-lajikkeiden viljelyä kohtaan (Areal et al. 2011). EU-politiikan ristiriitaisuus on hämmentävää. Vain kaksi siirtogeenistä lajiketta (Bt-toksiinia tuottava maissi ja Amflora tärkkelysperuna) ovat saaneet viljelyluvan EU:n alueella. Kuitenkin yhteensä 39:ää lajiketta saa tuoda EU:n alueelle. EU siis toisaalta kieltää GM-lajikkeiden viljelyn omilta viljelijöiltään turvallisuusriskeihin vedoten, mutta toisaalla tuo samoja lajikkeita ulkomailta. Muun muassa EU:hun tuodusta soijasta ja puuvillasta yli $80 \%$ on geenimuunneltua.

EASAC (European academies Science Advisory Council) julkaisi kesäkuussa 2013 raporttinsa geenitekniikan mahdollisuuksista ja haasteista kasvinjalostuksessa (raportti luettavissa osoitteessa www.easac.eu). USA, Australia, Kanada, Argentiina, Brasilia ja Kiina tuottavat suurimman osan maailman vilja- ja öljykasveista. Nämä maat ovat myös hyödyntäneet laajasti GM-lajikkeita. Kaupallinen GM-lajikkeiden viljely alkoi vuonna 1996, jolloin viljelypinta-ala oli 1.7 miljoonaa hehtaaria. Vuoteen 2012 mennessä viljelyala oli noussut yli 170 miljoonaan hehtaariin. 


\section{Modernin kasvinjalostuksen tulevaisuudennäkymät}

Kasvibiotekniikka on kehittynyt huimasti siitä kun agrobakteerivälitteinen geeninsiirto onnistuttiin valjastamaan tieteen käyttöön 30 vuotta sitten. Niin sanotut uuden sukupolven geenitekniikan menetelmät mahdollistavat sïrtogeenin tarkan kohdentamisen kohdekasvin genomiin ja puhutaankin kohdennetusta genomin muokkauksesta. Vain muutamia vuosia sitten tutkijat löysivät Xanthomonas bakteerisuvusta mekanismin, jolla kyseiset bakteerit pystyvät vaikuttamaan kasvin geenien säätelyyn omaksi edukseen (Boch ja Bonas 2010, Bogdanove et al. 2010). Bakteerisolut tuottavat proteiineja, jotka pystyvät katkomaan kasvin DNA:ta juuri tietystä kohdasta. Tutkijat oppivat hyödyntämään tätä luonnollista mekanismia ja periaatteessa mikä tahansa kasvin geeni voidaan esimerkiksi hiljentää tai aktivoida tällä menetelmällä. Ensimmäisiä näin tuotettuja kasvibiotekniikan sovelluksia on ollut tautikestävän riisilajikkeen kehittäminen ( $\mathrm{Li}$ et al. 2012). Uusimmassa genomin kohdennettuun muokkaukseen soveltuvassa CRISPR menetelmässä hyödynnetään bakteerien omaa puolustusjärjestelmää, joka sekin perustuu DNA-juosteiden katkaisemiseen tietystä halutusta kohdasta (Sorek et al. 2013). Poikkeuksena perinteisiin kasvibiotekniikan menetelmiin monet uuden sukupolven menetelmillä kehitetyt kasvilajikkeet eivät geenitekniikkalain määritelmän mukaan ole siirtogeenisiä organismeja, koska ne eivät sisällä lainkaan vierasta DNA:ta. Sen sijaan kasvin omaa genomia on muokattu halutun ominaisuuden jalostamiseksi. Pian EU:n on otettavaa kantaa siihen miten se suhtautuu näihin uusiin menetelmiin. Vielä ei ole myöhäistä modernisoida EU:n maatalouspolitiikkaa. Kukin kasvilajike pitäisi arvioida sen ominaisuuksien perusteella, eikä tekniikan, jolla se on jalostettu.

\section{Viitteet:}

Angenon G., Van Lijsebettens M. \& Van Montagu M. (2013). From the tumor-inducing principle to plant biotechnology and its importance for society. Int. J. Dev. Biol. 57, 453-460.

Areal, F.J., Riesgo, L., Rodriguez-Cerezo, E., (2011). Attitudes of European farmers towards GM crop adoption. Plant Biotechnol. J. 9, 945-957

Boch, J. and Bonas, U. (2010) Xanthomonas AvrBs3 family-type III effectors: discovery and function. Annu. Rev. Phytopathol. 48, 419-436

Bogdanove, A.J., Schornak, S., Lahaye, T. (2010). TAL effectors: finding plant genes for disease and defense. Curr. Opin. Plant. Biol. 13, 394-401

Brunaud V, Balzergue S, Dubreucq B, Aubourg S, Samson F, Chauvin S, Bechtold N, Curaud C, DeRose R, Pelletier G, Lepiniec L, Caboche M, Lecharny A. (2002). T-DNA integration into the Arabidopsis genome depends on sequences of pre-insertion sites. EMBO Rep. 2002 3, 1152-7

Li, T., Liu, B., Spalding, M.H., Weeks, D.P., Yang, B. (2012). High efficiency TALEN-based gene editing produces disease resistant rice. Nat. Biotechnol. 30, 390-392

Masip, G., Sabalza, M., Perez-Massot, E., Banakar, R., Cebrian, D. Twyman, R.M., Capell, T., Albajes, R., Christou P. (2013). Paradoxical EU agricultural policies on genetically engineered crops. Trends Plant Sci. 18, 312-324

Sorek R., Lawrence C.M., Wiedenheft B. (2013): CRISPR-mediated adaptive immune systems in bacteria and archaea. Annu. Rev. Biochem. 82, 237-266

Van Montagu M. (2011). It is a long way to GM agriculture. Ann. Rev. Plant Biol. 62, 1-23. 